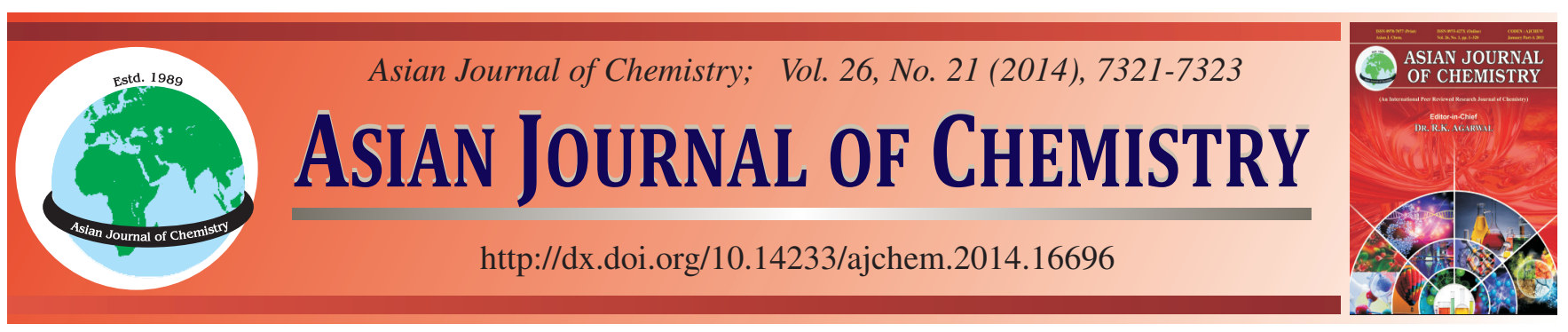

\title{
Antitumor Activity in vitro by 9-0xo-10,11-dehydroageraphorone Extracted from Eupatorium adenophorum
}

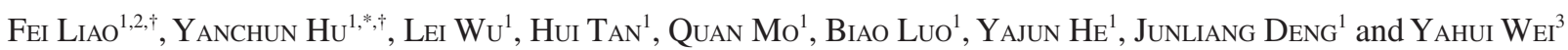

${ }^{1}$ Key laboratory of Animal Disease and Human Health of Sichuan Province, College of Veterinary Medicine, Sichuan Agricultural University, Sichuan Province, Ya an 625014, P.R. China

${ }^{2}$ Qiandongnan Prefectural Center for Disease Control and Prevention of Guizhou Province, Kaili 556000, P.R. China

${ }^{3}$ Key Laboratory of Resource Biology and Biotechnology in Western China, School of Life Science, Northwest University, Xi'an 710069, P.R. China

$†$ These authors contributed equally to this work and should be considered as first authors.

*Corresponding author: Fax: +86 835 2885302; Tel: +86 835 2885312; E-mail: yanchunhu@126.com

Received: 15 November 2013;

Accepted: 13 March 2014;

Published online: 30 September 2014;

AJC-16129

Ultrasonic-methanol extraction was used to extract cadenine sesquiterpene from Eupatorium adenophorum and then the crude 9-oxo10,11-dehydroageraphorone (euptox A) was purified by column chromatography and XAD-2 Macroporous Resin. 4,5-Dimethylthiazol2-yl)-2,5-diphenyltetrazolium bromide (MTT) assay was used to test the cytotoxicity of euptox A to human lung cancer A549 cells, Hela cells and Hep- 2 cells in vitro. The results suggest that euptox A had significant antitumor activity against the three tumor cell lines in vitro in a dose-dependent manner. When the concentration of euptox A was at $500 \mu \mathrm{g} / \mathrm{mL}$, the percent inhibition of human lung cancer A549 cells, Hela cells and Hep-2 cells were 76.42, 68.30 and $79.05 \%$, respectively. The $50 \%$ inhibitory concentration (IC I0 $_{5}$ ) of euptox A for the three tumor cell lines were 369,401 and $427 \mu \mathrm{g} / \mathrm{mL}$ (A549, Hela and Hep-2 cells, respectively). The results suggest it's better than the control of the 5-FU and euptox A may be considered as a potential candidate for developing a novel low toxicity antitumor agent.

Keywords: Euptox A, Antitumor activity, Eupatorium adenophorum.

\section{INTRODUCTION}

Eupatorium adenophorum spreng is a species of flowering plant in the daisy family known by many common names, including eupatory, sticky snakeroot, crofton weed and Mexican devil. After the introduction as a ornamental plant to USA in 1960s, it has spread worldwide ${ }^{1}$. As reported, several compounds have been separated and characterized from E. adenophorum spreng stem, flowers and leaves, including hemiterpenes, sterides, triterpenes, flavonoid and phenylpropanoids phenol etc. and have extensive biological activity. E. adenophorum can be used as a feed resource ${ }^{2}$, medical resource ${ }^{3}$ and chemical material resource ${ }^{4}$.

Euptox A is a cadenine sesquiterpene. A large number of reports indicate that the cadenine sesquiterpene have wide biological activities such as antitumor activity ${ }^{5}$, antigerminative activity $^{6}$, neurotrophic activity ${ }^{7}$, larvicidal activity ${ }^{8}$, antiprotozoal activity ${ }^{9}$. Previous studies have found that the euptox A from $E$. adenophorum had hepatotoxicity ${ }^{10}$ and allelopathy ${ }^{11}$. Our laboratory has shown that euptox A had highly acaricidal activity for $S$. scabiei and P. cuniculi in vitro ${ }^{12}$. But the antitumor activity of euptox A has not been investigated. Therefore, we had tested euptox A extracted from E. adenophorum by ultrasonic-methanol, column chromatography and XAD-2 against the human lung cancer A549 cell line, Hela cell line and Hep-2 cell line in vitro to identify its anti-tumor activity.

\section{EXPERIMENTAL}

E. adenophorum leaves were collected from Xichang City of Sichuan Province, Southwest China in July, 2012. The plant leaves were dried in the shade and broken into pieces. The ground material was stored in a dry environment, prior to extraction procedures.

Extraction procedure: Fifty grams of milled leaves were mixed with $100 \mathrm{~mL}$ water. The mixture contained euptox A, coumarin, gallotannic acid and volatile oils and was ultrasonic extracted by carbinol and hexyl acetate for $0.5 \mathrm{~h}$ at $40{ }^{\circ} \mathrm{C}$. In order to separate euptox A from the extract, samples were purified by silica column chromatography method and silica gel thin-layer chromatography and the final extract was then analyzed for euptox A. Quantification and toxin purity were demonstrated by high performance liquid chromatography (HPLC) $)^{13}$. HPLC (Agilent 1100 Series, USA) equipped with a Zorbax C-18 chromatographic column $(150 \times 4.6 \mathrm{~mm}, 5 \mu \mathrm{m})$. 
Sample volumes of $20 \mu \mathrm{L}$ were applied to a preparative the column at a flow rate of $1 \mathrm{~mL} / \mathrm{min}$. Two mobile phases were used for the gradient run (20\% water and $80 \%$ carbinol). Concentrations of euptox A was determined by calibration of the peak areas (at $255 \mathrm{~nm}$ ) with that of an external standard ${ }^{14}$.

In vitro cytotoxicity assay: The cytotoxicity of euptox $\mathrm{A}$ against human lung cancer A549 cells, Hela cells and Hep-2 cells was measured by the MTT assay ${ }^{15}$. The three cancer cell lines were maintained in DMEM supplemented with $10 \%$ fetal bovine serum, $100 \mathrm{mU} / \mathrm{L}$ streptomycin and $100 \mathrm{mU} / \mathrm{L}$ penicillin at $37{ }^{\circ} \mathrm{C}$ in a humidified atmosphere of $5 \% \mathrm{CO}_{2}$. Cells $(3 \times 103 /$ well $)$ in their exponential growth phase were seeded into each well of a 96-well flat-bottomed culture plate and incubated for $24 \mathrm{~h}$. Then three tumor cells were incubated with the samples (euptox A) at concentrations of $0,0.25,0.5$, 1 and $2 \mathrm{mg} / \mathrm{mL}$. After $48 \mathrm{~h}$, each well were added $20 \mu \mathrm{L}$ of $5 \mathrm{mg} / \mathrm{mL}$ of MTT and incubated for another $4 \mathrm{~h}$. After the culture media were removed, $150 \mu \mathrm{L}$ of DMSO were added to each well. Absorbance at $490 \mathrm{~nm}$ was detected by a microplate ELISA reader. 5-Fu was treated as positive control. The inhibition rate was calculated according to the formula below:

Growth inhibition rate $(\%)=\left(1-\frac{\text { Absorbance of experimental group }}{\text { Absorbance of control group }}\right) \times 100 \%$

Statistical analysis: All data are expressed as mean \pm SE and/or confidence interval. Statistical analyses were performed to compare the treated groups with the respective control group using a one-way analysis of variance (ANOVA) complemented with the Tukey-Kramer multiple comparison test with equal sample size. All computations were done by employing the statistical software (SPSS, version 20.0) ${ }^{16}$.

\section{RESULTS AND DISCUSSION}

Extraction and purification of euptox A: Euptox A was isolated from E. adenophorum leaves. The extracts were purified by column chromatography and XAD-2 macroporous resin. Quantification and the purity of the toxin were demonstrated by HPLC. The extract sample of the peak time is the same as the standard substance (Fig. 1). The purity of the toxin we had extracted was over $96 \%$.

In vitro cytotoxicity assay: To investigate the effects of extract treatment on cell viability, the endpoint of cytotoxicity (MTT) assays with human lung cancer A549 cell line, Hela cell line and Hep- 2 cell line were used and the results are presented in Table-1. The results showed euptox A had significant antitumor activity against the three tumor cell line in vitro in a dose-dependent manner. When the concentration of euptox A was at $500 \mu \mathrm{g} / \mathrm{mL}$, the percent inhibition of human lung cancer A549 cells, Hela cells and Hep-2 cells were 76.42, 68.30 and $79.05 \%$, respectively. The $50 \%$ inhibitory concentration $\left(\mathrm{IC}_{50}\right)$ of euptox $\mathrm{A}$ for the three tumor cell lines were 369, 401 and $427 \mu \mathrm{g} / \mathrm{mL}$ (A549, Hela and Hep-2 cells, respectively) (Fig. 2).

Cancer is a common and frequently-occurring disease that is a serious threat to human and animal life, its mortality rate is second after cardiovascular disease. At present, natural antineoplastic drugs have become the subject of much research. Natural products such as paclitaxol ${ }^{17,18}$, camptothecine $e^{19,20}$, podophyllotoxin $^{21}$, matrine ${ }^{22}$, vincristine ${ }^{23}$ have been shown to have anticancer activity. As recently demonstrated, euptox A extracted from E. adenophorum markedly inhibited the growth of cancer cells directly. Euptox A was found highly active against the fast growing A549, Hela and Hep-2 and its activity was concentration-dependent. A direct comparison with 5-FU in thes cell lines showed a clear superiority of euptox A, 5-FU is an antimetabolite that is used as a chemotherapeutic agent for a wide variety of cancers over 40 years $^{24}$. However, the antitumor activity of euptox A was obviously stronger than that of 5-FU at the same concentration. The reason is most likely that the test tumors had resistance to the 5-FU. Previous studies have found that the E. adenophorum had antitumor activity $^{25,26}$, but further study is required to determine if euptox $\mathrm{A}$ is the specific antitumor compound.

This study provides a new way for utilization of $E$. adenophorum. Euptox A has the potential to be developed as an antitumor drug. Further studies are warranted for clinical trials, animal acute toxicity test and safety evaluation.
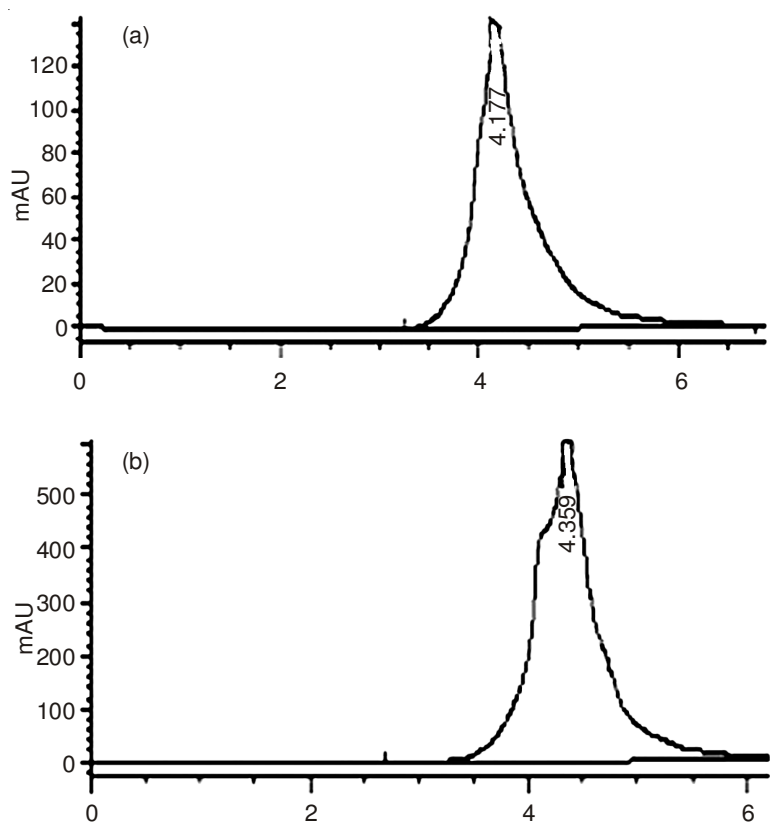

Fig. 1. HPLC of the standard substance and the extract sample. The standard substance of the peak time is $4.177 \mathrm{~S}$ (a). The extract sample of the peak time is $4.359 \mathrm{~S}(\mathrm{~b})$

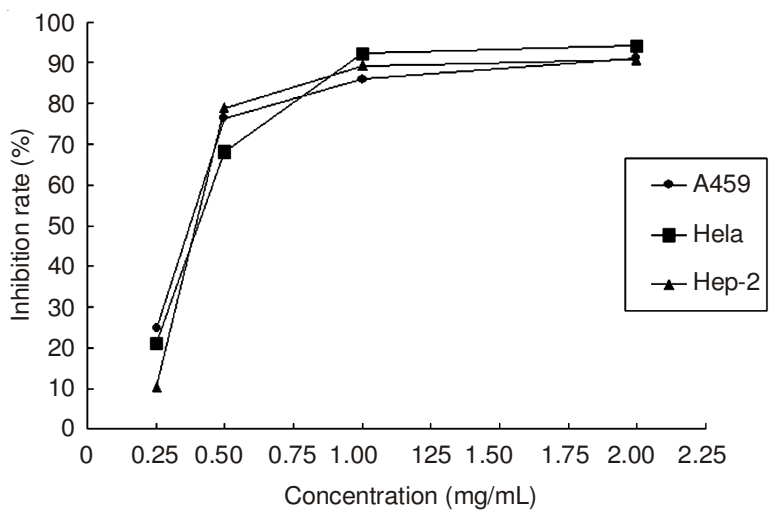

Fig. 2. Effect of treatment with Euptox A for the different doses tested $(0.25-2 \mathrm{mg} / \mathrm{mL}, 24 \mathrm{~h}$ of incubation) 


\begin{tabular}{|c|c|c|c|}
\hline $\begin{array}{r}\text { ACTIV } \\
\text { EXPOSED TO }\end{array}$ & $\begin{array}{l}\text { TABLE } \\
\text { N OF THREE } 1 \\
\text { ERENT CONCE }\end{array}$ & $\begin{array}{l}\text { MOR CELL LI } \\
\text { TRATIONS OF }\end{array}$ & $\begin{array}{l}\text { S } \\
\text { JPTOX A }\end{array}$ \\
\hline Treatment & $\begin{array}{c}\text { Concentration } \\
(\mathrm{mg} / \mathrm{mL})\end{array}$ & $\begin{array}{c}\mathrm{OD}(490 \mathrm{~nm}) \\
\text { Mean } \pm \mathrm{SE}\end{array}$ & $\begin{array}{c}\text { Inhibition } \\
\text { ratio }(\%)\end{array}$ \\
\hline A549 & & & \\
\hline Control & - & $1.724 \pm 0.245$ & 0 \\
\hline $5-\mathrm{Fu}$ & 1 & $0.350 \pm 0.020$ & 79.65 \\
\hline Euptox A & 0.25 & $1.298 \pm 0.150$ & 24.68 \\
\hline & 0.5 & $0.406 \pm 0.089$ & 76.42 \\
\hline & 1 & $0.244 \pm 0.030$ & 85.81 \\
\hline & 2 & $0.151 \pm 0.643$ & 91.21 \\
\hline Hela & & & \\
\hline Control & - & $2.790 \pm 0.226$ & 0 \\
\hline $5-\mathrm{Fu}$ & 1 & $0.487 \pm 0.064$ & 82.54 \\
\hline Euptox A & 0.25 & $2.201 \pm 0.393$ & 21.09 \\
\hline & 0.5 & $0.884 \pm 0.226$ & 68.30 \\
\hline & 1 & $0.218 \pm 0.024$ & 92.16 \\
\hline & 2 & $0.168 \pm 0.018$ & 93.95 \\
\hline Hep-2 & & & \\
\hline Control & - & $1.822 \pm 0.128$ & 0 \\
\hline 5-Fu & 1 & $0.622 \pm 0.108$ & 65.82 \\
\hline Euptox A & 0.25 & $1.632 \pm 0.180$ & 10.41 \\
\hline & 0.5 & $0.381 \pm 0.072$ & 79.05 \\
\hline & 1 & $0.197 \pm 0.015$ & 89.14 \\
\hline & 2 & $0.167 \pm 0.021$ & 90.79 \\
\hline $\begin{array}{l}\text { Note: The differ } \\
\text { within a column } \\
\text { data with the diff } \\
0.05 \text { ) }\end{array}$ & $\begin{array}{l}\text { between data } \\
\text { hificant }(\mathrm{P}<\mathrm{C} \\
\text { small letters } \mathrm{W}\end{array}$ & $\begin{array}{l}\mathrm{h} \text { the different } \\
\text { ) and the differ } \\
\mathrm{n} \text { a column is s }\end{array}$ & $\begin{array}{l}\text { pital letter } \\
\text { e between } \\
\text { ficant }(\mathrm{P}<\end{array}$ \\
\hline
\end{tabular}

\section{ACKNOWLEDGEMENTS}

This work was supported by the Special Fund for Agroscientific Research in the Public Interest (Grant No. 201203062) and the Raise Fund for Academic and Technical Leaders in Sichuan Province in 2014.

\section{REFERENCES}

1. Z.J. Lu and K.P. Ma, Weed Sci., 54, 1068 (2006).

2. A. Sahoo, B. Singh and O.P. Sharma, Livest. Sci., 136, 175 (2011).

3. K. Chakravarty, T. Mazumder and S.N. Chatterjee, Evid.-Based Complem. Altern. Med., Article ID 471074 (2011).
4. R.C. Padalia, D.S. Bisht, S.C. Joshi and C.S. Mathela, J. Essent. Oil. Res., 21, 522 (2009).

5. T. Kikuchi, K. Watanabe, Y. Tochigi, A. Yamamoto, M. Fukatsu, Y. Ezaki, R. Tanaka and T. Akihisa, Chem. Biodivers., 9, 1500 (2012).

6. S.V. Amand, A. Langenfeld, A. Blond, J. Dupont, B. Nay and S. Prado, J. Nat. Prod., 75, 798 (2012).

7. L. Trzoss, J. Xu, M.H. Lacoske, W.C. Mobley and E.A. Theodorakis, Chemistry, 19, 6398 (2013).

8. I. Montenegro, L. Pino, E. Werner, A. Madrid, L. Espinoza, L. Moreno, J. Villena and M. Cuellar, Molecules, 18, 4192 (2013).

9. A.A. Wube, F. Bucar, S. Gibbons, K. Asres, L. Rattray and S.L. Croft, Phytother. Res., 24, 1468 (2010).

10. R. Bhardwaj, A. Singh, O.P. Sharma, R.K. Dawra, N.P. Kurade and S.B. Mahato, J. Biochem. Mol. Toxicol., 15, 279 (2001).

11. X.Z. Zhu, J.T. Zhang and K.P. Ma, PloS one, 6, doi:25310.21371/ journal.pone.0025393 (2011)

12. F. Liao, Y. C. Hu, H. Tan, L. Wu, Y. Huang, Y. F. Wang, Q. Mo and Y. H. Wei, Exp. Parasitol., 140, 8 (2014).

13. L. He, J. Yang, A.C. Cao, Y.M. Liu, Y. An and J.-G. Shi, Chin. J. Chem., 24, 1375 (2006).

14. L. Ho, D. Hoefel, C.P. Saint and G. Newcombe, Water Res., 41, 4685 (2007).

15. A.T. Taher, H.H. Georgey and H.I. El-Subbagh, Eur. J. Med. Chem., 47, 445 (2012).

16. L. Zhang, S.R. Koyyalamudi, S.C. Jeong, N. Reddy, P.T. Smith, R. Ananthan and T. Longvah, Int. J. Biol. Macromol., 51, 1057 (2012).

17. I. Khan, M. Nisar, M. Ahmad, H. Shah, Z. Iqbal, M. Saeed, S.M.A. Halimi, W.A. Kaleem, M. Qayum, A. Aman and S.M. Abdullah, Fitoterapia, 82, 276 (2011)

18. Q. Xu, Y. Liu, S. Su, W. Li, C. Chen and Y. Wu, Biomaterials, 33, 1627 (2012).

19. D.P. Fulzele and R.K. Satdive, Fitoterapia, 76, 643 (2005).

20. B. Ramesha, H. Suma, U. Senthilkumar, V. Priti, G. Ravikanth, R. Vasudeva, T. Kumar, K. Ganeshaiah and R. U. Shaanker, Phytomedicine, 20, 521 (2013).

21. L. Qin, M. Xue, W. Wang, R. Zhu, S. Wang, J. Sun, R. Zhang and X. Sun, J. Essent. Oil Res., 388, 223 (2010).

22. J.Q. Zhang, Y.M. Li, T. Liu, W.T. He, Y.T. Chen, X.H. Chen, X. Li, W.C. Zhou, J.F. Yi, Z.J. Ren and J. World, Gastroentero., 16, 4281 (2010).

23. T. Zhang, Y. Zheng, Q. Peng, X. Cao, T. Gong and Z. Zhang, Int. J. Nanomed., 8, 1185 (2013).

24. F. Li, F. Wang, F. Yu, Y. Fang, Z. Xin, F. Yang, J. Xu, L. Zhao and Q. Hu, Food Chem., 111, 165 (2008).

25. Q. Yan, J. Yang, H. Li, A. Cao, Q. Chen, Y. Wen and L. He, J. Being Norm, Univ. Nat. (Sci. Ed.), 42, 70 (2006).

26. Y. Sato, S. Itagaki, T. Kurokawa, J. Ogura, M. Kobayashi, T. Hirano, M. Sugawara and K. Iseki, Int. J. Pharm., 403, 136 (2011). 